\title{
Collaboration between Marketing Students and the Library: An Experiential Learning Project to Promote Reference Services
}

\author{
Lynda M. Duke, Jean B. MacDonald, and Carrie S. \\ Trimble
}

As with most academic libraries, declining reference transactions has been a concern at Illinois Wesleyan University's Ames Library. After grappling with the problem unsuccessfully, librarians sought input from students on how to address this issue. Collaborating with a professor in the Business Administration Department, a two-class series focusing on real-world marketing issues took on the challenge of how best to promote reference services to students. Student-generated surveys and marketing ideas proved useful for making changes to the library's reference services and for publicizing the service, resulting in an increase in reference transactions between students and librarians.

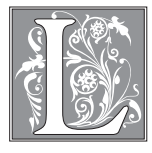

ike most libraries, The Ames Library has struggled in recent years to maintain student interest in using reference services. At Illinois Wesleyan University (IWU), a private liberal arts school with 2,100 students located in central Illinois, it was assumed that the new library, which opened in January of 2002, would help attract more students to the library and the reference desk.

Librarians had begun planning for the new library six years earlier. The old library, Sheehan, was small, unattractive, and dark-with a makeshift reference desk and not much foot traffic. Although student input was solicited as part of the planning process for the new library, the majority of questions in the survey related to the overall atmosphere and purpose of the building, as well as study space needs. For example, questions included in the survey focused on whether the library should be a "quiet place to study and/or a place for interaction with other students and faculty," and whether "students generally preferred to study alone, with one other person, or in groups." The only reference-related question dealt with location-with the majority of respondents expecting to find the reference desk on the first floor of the library. This lack of focus on reference services reflects the fact that, in 1996, declining reference desk use

Lynda M. Duke is Associate Professor, Academic Outreach Librarian in the Ames Library at Illinois Wesleyan University; Jean B. MacDonald is Visiting Associate Professor, Public Services Librarian in the Ames Library at Illinois Wesleyan University; and Carrie S. Trimble is Assistant Professor, Business Administration at Illinois Wesleyan University; e-mail: lduke@iwu.edu, jmadona@iwu.edu, ctrimble@iwu.edu. 
had not yet been identified as a concern at IWU. ${ }^{1}$

However, within a few years of moving to the new library, it was clear that declining reference transactions were a problem, reflecting a national trend. After grappling with the problem unsuccessfully, librarians at Ames realized they needed input from students on this issue. Serendipitously, a two-class series focusing on real-world marketing issues is offered in the Business Administration Department. The library liaison to the Business Administration department approached the professor teaching these courses, and the two agreed to collaborate on a joint project beginning in the spring of 2007. The results have been beneficial to the library as well as to the students taking the marketing classes.

\section{Literature Review}

A review of the library and business literature suggests that there are few other published examples of this particular type of collaboration. Particularly noteworthy are two cases: the collaboration between librarians and business students in a yearlong capstone course in business to develop a marketing plan for the library at California State University at San Marcos (CSUSM) and the alliance established between the Texas A\&M University Libraries and the American Advertising Federation Undergraduate Student Chapter to develop a marketing campaign promoting an electronic books service.

Similar to the project between The Ames Library and the IWU marketing classes, CSUCM's experience was designed to provide business students with the "...opportunity to apply marketing principles to a real world situation..." Meulemans and Fiegen note that saving staff time is one particular benefit of using students for creating and implementing surveys to discern use and awareness of library services among students and faculty. Given the myriad responsibilities of most librarians, it can be difficult for them to find time to design and carry out surveys. ${ }^{2}$ In addition, when students develop survey questions, they are relying on their intimate knowledge of their peers and their study habits.

Unlike the project at IWU, at Texas A\&M University Libraries the students' work not only focused on the development of a marketing campaign but also on the actual implementation of the campaign. This logical next step provides not only the opportunity for students to see the fruition of their work but also a needed reality check. In this case, students learned of the budgeting realities of an academic institution and the need to scale back their initial plans. ${ }^{3}$

A review of the marketing literature indicates that, in the last two decades, marketing educators have begun to embrace experiential learning methods as a way to help students learn marketing techniques. ${ }^{4}$ Marketing is such a broad topic that marketing educators themselves can rarely provide definitive examples of successful marketing practices. The lack of specific "how-tos" in marketing can be frustrating to marketing students.

Most experiential learning projects involve a "real world" client who expects the marketing students to figure out their own "how-tos" and then to make recommendations to the client. Requiring students to gain practical marketing experience within the framework of a marketing course may not totally alleviate students' frustration regarding the lack of "how-tos," but it can at least help illustrate why definitive examples are lacking. Ideally, working with the client takes marketing concepts far beyond the boundaries of a textbook and provides students a realistic context ${ }^{5}$ and can help them develop problem-solving and teamwork skills that they will continue to use after graduation. ${ }^{6}$

While valuing the benefits of experiential learning, educators also recognize the difficulty of engaging students enrolled in lower-level marketing courses in a practical marketing experience when 
those students typically lack a firm grasp of marketing concepts. ${ }^{7}$ One common way to overcome this obstacle is to find a client accustomed to volunteers without formal training, such as not-for-profit organizations (NPOs). When an experiential learning project involves an NPO, the project is typically deemed a service learning project. However, even when assigned a service learning project with an amenable NPO for a client, marketing educators recognize that it is important to limit the scope of the project for the benefit of the client as well as the marketing students. ${ }^{8}$

\section{Declining Reference Services Statistics}

Academic libraries throughout the United States have noted a decline in traffic at the reference desk, and Ames Library was no different. One study noted a 37 percent decrease in reference transactions at private academic libraries in the United States between 1995 and 2004. ${ }^{9}$ Before moving into the new library, reference statistics revealed a desk moderately busy, with close to 2,000 reference transactions for the year 2000. After moving into the new, classically appointed, yet technologically modern library in January of 2002, the reference numbers continued to decline. By 2005, the total number of reference questions at Ames was closer to 800 .

This drop in reference interactions was disturbing to the librarians at Ames - particularly given their belief that offering reference services is a significant component of their work with students and faculty. The librarians at Ames operate on the assumption that most students entering college need assistance understanding the scope of sources available to them through the library and how best to access, evaluate, and incorporate these resources into their research. With the reference service statistics in serious decline, the librarians were concerned that students were not using the library and its resources to its full potential.
The new L-shaped, bilevel information desk was designed so that student assistants would be the first points of contact for individuals approaching the desk for assistance. The desk was designed so that they would sit at the higher level, at the intersecting corner of the "L," and the librarians would sit at the lower level, at the top end of the "L." This design decision was intended to make approaching the desk for help less intimidating for students - following the theory that students are more comfortable talking to their peers rather than to a librarian. ${ }^{10}$ In addition, library literature reveals that students find a counter-height reference desk more approachable than a tableheight desk. ${ }^{11}$ However, this design created a situation where librarians did not have a lot of opportunity to interact with students unless they chose to approach the librarian directly or the student assistant referred the inquiring student to a librarian. Librarians at Ames felt the loss of reference interaction sorely.

Due to various staffing changes, in 2007 a visiting librarian (that is, a librarian serving as a replacement during the leave of a tenured librarian) was charged with overseeing reference services and investigating potential changes to the service. Specifically, this librarian was asked to lead discussions with the other library faculty to discover the implications of possible changes to reference services. Modifications were to be done in keeping with the recently adopted strategic plan initiative. The desire of the library was to seek high-impact, low-cost, short-term changes to reference services.

The overhaul of reference service delivery at Ames had been attempted once before, in 2005, with less than satisfactory results. The team consisted of four librarians and a staff member and was charged with developing a plan for revising reference services. The team spent significant time reviewing the issues involved and the relevant literature to learn what other libraries were doing to address low usage of reference services. A report with 
various proposals was put forth in the summer of 2005. However, due to various sabbatical leaves, staffing changes, and internal politics, the library was never able to move beyond the discussion stage and the proposals were never endorsed or adopted by the librarians. In short, no changes to the information desk or the delivery of reference services were implemented.

With the history of past attempts at addressing the reference initiative explained to - but not experienced by — the visiting librarian, she began to address the issue. Her first planned step was to survey IWU students concerning their perceptions of reference services, then to use those results to formulate a plan for further action with respect to the desk, its staffing, and services.

It was at this juncture that the convener of the Library Marketing Team (LMT) began discussions with a professor in Business Administration regarding the possibility of working with marketing students to find a way to increase reference interactions at IWU. The previous year, the LMT had begun to seek student input on their marketing activities and promotional items. This informal effort proved useful, and the LMT felt that a more formalized collaboration would help the library to better understand what students thought of reference services and how best to market the service.

After some discussion, the LMT chair, the librarian charged with investigating possible solutions to reference services, and the professor of marketing gladly agreed to work collaboratively. Together, they designed a marketing class assignment that required marketing students to measure student awareness of the library's reference services and to develop suggestions to increase students' use of these services.

\section{Spring 2007 Business Marketing Class: Survey Assignment}

The students from two sections of an introductory marketing class were tasked with creating a survey that would provide information about IWU student opinions of the Ames Library and its reference services, a process referred to as a "current situation analysis" in marketing circles. After considering the survey results, the marketing students were asked to provide recommendations for increasing the interaction between IWU students and reference services. This service learning opportunity presented by the library fulfilled the team project requirement for the course.

As previous research on service learning suggests, one of the difficulties of allowing students from an introductory marketing course to develop an experiential learning project is lack of the very experience the project would provide. ${ }^{12}$ Therefore, the scope of this project was intentionally limited to creating and administering an online survey meant to gauge IWU student awareness of the library and its services and to delineate their study habits - an ideal servicelearning project for students new to marketing concepts.

The LMT presented the students with a few requirements for the survey; but, recognizing that IWU students would best understand the survey participants (their peers), the LMT allowed the students in the marketing course to generate the bulk of the survey questions. In addition to the basic demographic questions establishing each respondent's year in school and declared major, the survey participants were asked to identify when they were last in the library and the reason for that visit. In addressing the reference services concerns directly, the LMT requested that the survey include items that asked participants if they had ever consulted a librarian for research assistance and their reasons for choosing to engage in or avoid such a consultation.

The use of two sections of the marketing course increased the sample size and allowed for the development of two versions of the survey. All participants in the survey answered the previously 
mentioned items. While one survey version focused on students' knowledge and use of reference services, the other version focused on students' habits for completing assignments. As a convenience survey, participants were not randomly selected. Students recruited their classmates, roommates, and other acquaintances to participate; thus, the results do not necessarily reflect a representative sample. The total number of participants was 91 for the first class and 42 for the second.

In the second version of the survey, participants were asked to rank the order of sources they used to answer a specific question, to begin a research project, to troubleshoot computer problems in the library and to use a style guide. The list of possible sources included a friend or classmate, the Internet (primarily a Google ${ }^{\circledR}$ search), a librarian, the library Web site, and a professor. In addition to identifying the order in which they would consult these sources, participants were asked to identify how much time they would spend with a particular source before moving on to the next source.

The survey results confirmed the Ames librarians' beliefs that IWU students are fond of the Ames Library and its librarians, but IWU students fail to use the library's resources to their fullest. Specifically, 75 percent of the 224 participants had visited the library in the last week and the librarians were described as "helpful" and "smart," but less than half of the participants had ever consulted an Ames librarian. Primarily, the survey results were consistent with the Millennial Generation's identified traits of self-assuredness, technological savvy, and impatience. ${ }^{13}$ The most frequently cited reason for not consulting a librarian was the belief that the participants did not need the assistance of reference services. Additionally, when asked to indicate the frequency of use of the Ames reference services, the participants displayed an unwillingness to ask for help. Specifi-

\begin{tabular}{|l|c|}
\hline \multicolumn{2}{|c|}{$\begin{array}{c}\text { TABLE 1 } \\
\text { Desiptive Information } \\
\text { about the Sample }\end{array}$} \\
\hline Major & $\begin{array}{c}\text { \% of } \\
\text { Respondents* }\end{array}$ \\
\hline Biology & 6.7 \\
\hline Business Administration & 10.7 \\
\hline Chemistry & 1.8 \\
\hline Computer Science & 1.8 \\
\hline Economics & 4.0 \\
\hline Education & 6.9 \\
\hline English & 6.3 \\
\hline Environmental Studies & 1.3 \\
\hline German & 0.4 \\
\hline Greek and Roman Studies & 0.4 \\
\hline Hispanic Studies & 1.8 \\
\hline History & 2.2 \\
\hline International Studies & 2.7 \\
\hline Mathematics & 1.3 \\
\hline Music Theatre & 0.4 \\
\hline Musical Performance & 1.2 \\
\hline Nursing & 5.3 \\
\hline Philosophy & 0.8 \\
\hline Physics & 1.8 \\
\hline Political Science & 4.9 \\
\hline Psychology & 8.9 \\
\hline Sociology & 0.8 \\
\hline Women's Studies & 0.4 \\
\hline *Freshman: 13.4\%, Sophomore: $24.6 \%$, \\
Junior: 38.5\%, Senior: 24.1\% \\
\hline
\end{tabular}

cally, when asked how often they used the available reference services, over 85 percent of the participants indicated that they simply do not usually ask for help. (See table 2 for more detail.)

Survey items designed to measure students' habits in completing assignments highlighted the participants' comfort with technology. To answer a specific question, 67 percent of the participants turned to Google $^{\circledR}$ and the Internet as their primary or secondary source. (See table 3.) Not 
TABLE 2

Awareness and Frequency of Use of the Ames Library Reference Services

\begin{tabular}{|l|c|c|c|c|c|}
\hline \hline \multicolumn{1}{|c|}{$(\boldsymbol{n}=\mathbf{1 3 3})$} & \multicolumn{2}{|c|}{ Awareness } & \multicolumn{3}{c|}{ Frequency } \\
\hline & Yes & No & $\begin{array}{c}\text { Don't ask } \\
\text { for help }\end{array}$ & $\begin{array}{c}\text { Maybe } \\
\text { once }\end{array}$ & $\begin{array}{c}\mathbf{1 - 5} \\
\text { times }\end{array}$ \\
\hline Reference desk & $86.5 \%$ & $11.3 \%$ & $85.0 \%$ & $11.3 \%$ & $0.8 \%$ \\
\hline “Ask a Librarian" Web page & $39.1 \%$ & $58.6 \%$ & $95.5 \%$ & $1.5 \%$ & $0.0 \%$ \\
\hline Appointment with an Ames librarian & $50.4 \%$ & $47.4 \%$ & $94.0 \%$ & $2.3 \%$ & $0.0 \%$ \\
\hline
\end{tabular}

surprisingly, when beginning a research project, 59 percent of those surveyed chose Google $^{\circledast}$ and the Internet as their first or second source while an overwhelming 74 percent looked for citation information through style guides online. (See tables 4 and 5 for more detail.)

Additionally, when completing these tasks, the survey respondents demonstrated a tendency to engage the Ames Library Web site instead of the Ames librarians. To answer a specific question, the Ames Web site (28\%) was more popular than the librarians (3.3\%) as the first or second source. For beginning a research project, the difference was even greater, as 51 percent of participants claimed the
Ames Web site as a first or second choice to the four percent who claimed a librarian. Alarmingly, no participants reported that they would begin a research project by consulting a librarian.

Only in troubleshooting a library computer problem were the librarians (66\%) a preferred source to the technological options of Google ${ }^{\circledR}(25 \%)$ and the library Web site $(25 \%)$. However, even in completing that task, survey participants preferred to engage their friends (72\%). (See table 6.)

When asked how long they worked with a source before moving on to another, survey participants indicated that they would move on after fifteen to thirty minutes. While this finding, like those

TABLE 3

Ranking of Sources Used for Answering a Specific Question

\begin{tabular}{|l|c|c|c|c|c|}
\hline \hline \multicolumn{1}{|c|}{$(\boldsymbol{n}=\mathbf{9 1})$} & 1st choice & 2nd choice & 3rd choice & 4th choice & 5th choice \\
\hline Google/Internet & $49.5 \%$ & 17.6 & $14.3 \%$ & $11 \%$ & $4.4 \%$ \\
\hline Professor & $24.2 \%$ & $23.1 \%$ & $30.8 \%$ & $14.3 \%$ & $5.5 \%$ \\
\hline Friend & $17.6 \%$ & $34.1 \%$ & $23.1 \%$ & $7.7 \%$ & $15.4 \%$ \\
\hline Ames Web site & $5.5 \%$ & $22.0 \%$ & $16.5 \%$ & $70.5 \%$ & $13.2 \%$ \\
\hline Ames librarian & $2.2 \%$ & $1.1 \%$ & $13.2 \%$ & $23.1 \%$ & $59.3 \%$ \\
\hline
\end{tabular}

\section{TABLE 4}

Ranking of Sources Used for Beginning a Research Project

\begin{tabular}{|l|c|c|c|c|c|}
\hline \hline \multicolumn{1}{|c|}{$(\boldsymbol{n}=\mathbf{9 1})$} & 1st choice & 2nd choice & 3rd choice & 4th choice & 5th choice \\
\hline Professor & $41.8 \%$ & $18.7 \%$ & $19.8 \%$ & $12.1 \%$ & $5.5 \%$ \\
\hline Google/Internet & $27.5 \%$ & $31.9 \%$ & $26.4 \%$ & $7.7 \%$ & $4.4 \%$ \\
\hline Ames Web site & $20.9 \%$ & $29.7 \%$ & $12.1 \%$ & $26.4 \%$ & $8.8 \%$ \\
\hline Friend & $7.7 \%$ & $14.3 \%$ & $25.3 \%$ & $17.6 \%$ & $34.1 \%$ \\
\hline Ames librarian & $0.0 \%$ & $4.4 \%$ & $14.3 \%$ & $34.1 \%$ & $45.1 \%$ \\
\hline
\end{tabular}




\begin{tabular}{|l|c|c|c|c|c|}
\hline \multicolumn{7}{|c|}{ TABLE 5 } \\
Ranking of Sources Used for Using a Style Guide for Class \\
\hline \hline \multicolumn{1}{|c|}{$(\mathbf{n = 9 1 )}$} & $\mathbf{1 s t}$ choice & 2nd choice & 3rd choice & 4th choice & 5th choice \\
\hline Google/Internet & $49.5 \%$ & $24.2 \%$ & $16.5 \%$ & $5.5 \%$ & $2.2 \%$ \\
\hline Friend & $19.8 \%$ & $29.7 \%$ & $19.8 \%$ & $9.9 \%$ & $18.7 \%$ \\
\hline Professor & $18.7 \%$ & $19.8 \%$ & $19.8 \%$ & $18.7 \%$ & $20.9 \%$ \\
\hline Ames librarian & $5.5 \%$ & $7.7 \%$ & $13.2 \%$ & $18.6 \%$ & $38.5 \%$ \\
\hline Ames Web site & $4.4 \%$ & $15.4 \%$ & $28.6 \%$ & $34.1 \%$ & $14.3 \%$ \\
\hline
\end{tabular}

\begin{tabular}{|c|c|c|c|c|c|}
\hline \multicolumn{6}{|c|}{$\begin{array}{c}\text { TABLE } 6 \\
\text { Ranking of Sources Used for Troubleshooting a Computer Problem at the } \\
\text { Ames Library }\end{array}$} \\
\hline$(n=91)$ & 1st choice & 2nd choice & 3rd choice & 4th choice & 5th choice \\
\hline Friend & $47.3 \%$ & $24.2 \%$ & $12.1 \%$ & $12.1 \%$ & $1.1 \%$ \\
\hline Google/Internet & $11.0 \%$ & $14.3 \%$ & $23.1 \%$ & $24.2 \%$ & $9.8 \%$ \\
\hline Ames librarian & $33.0 \%$ & $33.0 \%$ & $19.8 \%$ & $5.5 \%$ & $2.2 \%$ \\
\hline Ames web site & $5.5 \%$ & $19.8 \%$ & $28.6 \%$ & $31.9 \%$ & $6.6 \%$ \\
\hline Professor & $0.0 \%$ & $5.5 \%$ & $8.8 \%$ & $16.5 \%$ & $62.6 \%$ \\
\hline
\end{tabular}

previously mentioned, dovetails with the identified traits of the Millennials (short attention spans), the survey's results suggested that overcoming generational tendencies was not the only difficulty facing the Ames Library. Importantly, a general lack of knowledge of the available references services was reported. While survey participants were well aware of the reference desk $(87 \%)$, a number of them reported that they did not know IWU students could make an appointment to talk with a librarian $(47 \%)$ or use the "Ask A Librarian" Web page (57\%) to ask a question. The latter statistic is perhaps most troubling given the survey participants' comfort with online resources. Increasing students' awareness of the "Ask A Librarian" Web page could conceivably help increase interaction between IWU students and the Ames librarians.

Based on the survey results and their own beliefs about their peers, the students from the marketing course recommended that the LMT embrace the nature of the Millennial students and the general nature of college students. As self-assured Internet users, the marketing students felt that an instant messaging service would increase traffic to reference services. Instant messaging, in particular, was recommended because it combined students' reticence to engage the librarians faceto-face with the students' comfort with technology, their short attention spans, and a desire for immediate results.

The marketing students also reminded the LMT of another aspect of Millennials that could be used to help promote the use of the library reference services: typical Millennials generally follow the rules and willingly accept authority figures. ${ }^{14} \mathrm{In}$ other words, incorporating learning experiences about Ames reference services into course requirements would not seem out of the ordinary to IWU students. Finally, the marketing students recommended the creation of walk-in workshops to demonstrate how specific assignments or research projects could be completed with the assistance of reference librarians.

\section{The Library's Response to the Marketing Survey}

The marketing professor sent copies of the students' final reports to the library (with 
identifying information removed), and they were circulated among the librarians. The final reports addressed the visibility and functionality of reference services. The visiting librarian led a discussion detailing the student findings and outlining possible changes to reference services.

One item that became obvious after perusing the surveys was that the words "reference" and "information" had little to no meaning to students. To many librarians, this finding was surprising, whereas other librarians expected this result. In any case, it served as a reminder to the librarians that the sign advertising our services (a sign that reads "Information Desk") and the terminology librarians often use to promote working with a librarian (reference) may not be as effective as we think or would like them to be.

After much discussion, it was determined that additional signage would be appropriate at the information desk. Drafts were circulated among the library faculty and student assistants, and a picture of a red button with a question mark was adopted as the secondary sign to highlight reference services. This "help button" sign hangs immediately below the more formal sign that still reads "Information Desk."

As noted above, the marketing students strongly advocated adding an Instant Messaging (IM) reference service. After the library faculty endorsed such a venture, the visiting librarian reviewed various software packages used for IM reference, ultimately choosing Meebo because of its ability to work with AIM, Yahoo, Google ${ }^{\circledR}$ Talk, and MSN chat software. The fact that the Meebo widget could be embedded into library Web pages made the decision exceptionally simple. Its high visibility promised a great opportunity to promote reference interactions with anyone visiting the library via its Web pages.

To complement the launch of the new IM reference service, the visiting librarian worked closely with the LMT to develop a strategy for marketing the new service.
In addition to announcements posted on the campus Web portal and an article in the weekly student newspaper, The Argus, the LMT ordered 2,000 whiteboards designed to look like the Meebo widget with the hours of IM availability. These whiteboards were distributed to every student living on campus, both in the residence halls and the Greek houses. Additionally, a supply was left on a table in the library in the hope that students living off-campus would also pick up a whiteboard and take one home to post in a noticeable place.

Strengthening awareness of the e-mail reference service was another issue that came to light in survey results, and this was also addressed. The LMT ordered small key chains with pen lights to give to each incoming first-year and transfer student (approximately 600 students). Printed on the key chains was the Web address of a page highlighting the various ways in which a student can contact a librarian: IM, e-mail, phone, office hours, by appointment, and desk hours. Librarians gave these popular items to students during their registration orientation sessions, where information is provided by campus technology staff on the registration process and librarians provide an overview of ways to get help with assignments, research papers, and final projects. It proved to be an effective way to talk about the new IM service as well as all the other ways in which students can work with librarians.

The marketing students also suggested that the library offer walk-in workshops to students on specific topics of interest. After some discussion, the library faculty decided that they did not believe that offering these types of classes would be as valuable a use of staff time as more directed offerings (such as instruction sessions directly linked to class assignments). However, taking into consideration this suggestion by the students, librarians sought to cultivate relationships with Greek societies, sports teams, and residence halls in an effort to provide 
information directly applicable to student needs. A handful of these groups scheduled time with a librarian to learn how to improve their grades or bolster research skills.

The final proposal proffered by the spring marketing class was direct marketing to students about services the library offers with respect to specific assignments. Unsure how to progress in this arena, the business liaison librarian and the visiting librarian again approached the marketing professor to see if she might be interested in having the students in her integrated marketing communications class adopt this particular aspect as a final project. Once again, all parties involved embraced this notion; the library's need to promote reference services coalesced with the marketing professor's desire to use real-world examples.

\section{Fall 2007 Marketing Class: Promotional Campaigns}

Following the success of replacing a research-based team project with a service learning project in the introductory marketing course, IWU marketing students in an integrated marketing communications course (IMC) were asked to create a promotional campaign for the library's reference services as part of a team-based service learning opportunity. The introductory marketing course is a prerequisite for enrollment in the IMC seminar, so students engaged in this project have some experience with marketing concepts. Therefore, it was appropriate for this project to have a greater scope than the project assigned to the students in the introductory marketing course that was taught in the spring.

Three teams (The Office Team, Ames Saves Time Team, and The Not Cheating Team) of marketing students were assigned the task of evaluating the survey data and recommendations compiled by the introductory course students, in order to write a creative brief for a promotional campaign for the LMT. A creative brief typically outlines the specific situation or problem at hand and the strategy necessary to meet the set objectives.

In this case, the IMC students felt that IWU students' lack of awareness of the reference services was the initial obstacle. However, the higher hurdle to cross was IWU students' reluctance to ask for assistance. Based on the objectives of increasing awareness and creating more positive attitudes toward interacting with various reference services, each of the three teams created a campaign that included an electronic component (either a video or a podcast), a print ad, a direct marketing element, and an interpersonal promotional piece. For the interpersonal element, the teams could create a customer service module, a public relations event, or a viral marketing item. (Viral marketing is an umbrella term for most nontraditional and grassroots forms of promotion meant to encourage word of mouth communication.)

All three teams considered the Millennial Generation's desire to be entertained, ${ }^{15}$ setting a lighthearted tone for their campaigns. The Office Team focused primarily on increasing awareness of the available reference services and created a short video parody of the popular television show The Office to introduce a symbol that could be placed wherever references services were offered. The Ames Saves Team also set a lighthearted tone in a video demonstrating that students could spend more time playing "Guitar Hero" when they used the Ames Library reference services to complete assignments and projects in an efficient manner. The Not Cheating Team focused on creating more positive attitudes toward interacting with reference services. They created the slogan "Just ask! Just because they have the answers doesn't make it cheating!"

Just as the students from the introductory marketing course did, the IMC students understood the need to demonstrate how using the Ames Library reference services can meet a specific need for a student. All three teams created strong direct marketing pieces that 
would showcase how IWU students could use the Ames reference services to complete a specific assignment or research project. The Not Cheating Team created the direct marketing element with the most practical and beneficial application. That team's concept was to create a divider for the IWU student planner that included major specific uses of Ames' reference services. For example, a senior Business Administration major would receive a planner divider that listed the research project from the senior capstone strategy course. The removable divider would benefit the students by acting as a constant reminder of reference services information (hours, subject specialist information, and contact data) conveniently placed where a student would be likely to record course assignment details and deadlines. Therefore, when students check their calendars, the reference information is available when students are thinking about completing assignments.

Another strong theme throughout the campaigns was the necessity of getting students involved with librarians and not simply into the library building. The Not Cheating Team used chalking the campus sidewalks as their viral marketing element, inviting students to talk to librarians outside the library building. The Ames Saves Team went even further by recommending that Ames Library host a carnival within the building. To play the carnival games and win prizes, students would first be obligated to interact with the different facets of the Ames reference services.

\section{The Library's Planned Response to the Promotional Campaigns}

The Not Cheating Team's use of the slogan "Just ask! Just because they have the answers doesn't make it cheating!" to instill the habit of asking librarians for help among first-year students intrigued the librarians. Of perhaps the greatest interest was the revelation that asking for help from a librarian might somehow be construed as cheating in students' minds. The group's suggestion of creating ways to meet with students outside the library so that the students could interact with librarians in more neutral territory and to set up personalized appointments for "homework help" is appealing to many of the librarians and presents the first option for consideration.

The Office Team's plan to adopt the "help button" image as a brand symbol for identifying reference services is another avenue the LMT and library faculty are exploring. The LMT is considering creating mailers (both print and e-mail fliers) to IWU faculty with the "help button" image, asking them to integrate the image into their syllabus, and to tell their students to look for the symbol as a place to find research help. Further incorporating the use of the "help button" as an identifier of reference services on the library Web page alongside the Meebo widget, and in any and all other reference-related services, is also appealing.

The slogan "Ames Saves Time," developed by the Ames Saves Team, is also attractive as it works to improve student awareness of reference services and its benefits. While the library faculty is less enthusiastic about the notion of hosting a carnival (the mess! the noise! the setup and takedown!), the notion of adopting a more student-oriented experience is noteworthy.

Each of the three plans developed by the students has aspects the library hopes to use-either directly or in a modified form. Using information from the student surveys conducted in the spring of 2007 and the direct marketing plans developed by the marketing classes in the fall of 2007 will help to ensure a student-centered approach to marketing reference services in the future. While it is too soon to know exactly what programs or initiatives the library will adopt, having a better understanding of students' perceptions and having input from students on possible avenues to explore is useful. 


\section{Collaborative Project's Impact on Reference Services Statistics}

As a direct outgrowth of the collaboration between librarians and the marketing professor (and the students in her two courses), librarians addressed the student/librarian configuration at the information desk. In the fall of 2007, librarians assumed the former student assistant position at the desk (at the higher, more approachable section of the " $\mathrm{L}$ ") and student assistants started using the space immediately adjacent-yet at a right angle from - the new librarian station. This change was consistent with the findings in the literature regarding student preference for counter-height reference desks and also substantially increased the visibility of the librarian (previously she/he was seated not only at a lower level, but tucked behind the higher-level portion of the reference desk, making it very easy to miss the presence of the librarian altogether). A computer is still available at the ADA-compliant lower station of the information desk should a patron with special needs seek reference service.

The impact of the working relationship between the library and the marketing classes in conjunction with the rearrangement of the desk has been noteworthy, especially in light of past experiences. Transactions as noted on weekly tally sheets kept at the desk and documented by librarians revealed 311 questions for the month of November 2004. By November 2005, that number fell to 125 , and exactly one year later it reached its nadir with 115. In November 2007, with librarians assuming the more front-andcenter desk location and adopting IM software for increased availability for interactions, librarians put 187 marks on the tally sheets, with 65 questions coming via the Meebo widget and the remaining 122 coming to us predominantly through conventional visits to the information desk. Overall, the statistics reveal an upward bounce in the number of librarian interactions from 2006 to 2008 during the first quarter of those years. A decrease in student-to-student contact during this time frame is also demonstrated. Interestingly, aggregate numbers are still trending downward, though in a decidedly less dramatic form. Clearly, students are approaching librarians more frequentlyboth physically and electronically - and librarians could not be happier with the increased business.

\section{Conclusion}

From the standpoint of the library, the collaboration between the marketing classes and the library has been rewarding and productive. After many years of frustration, we were able to move beyond our inertia and begin to implement changes to our reference services. This experience has proved to be highly instructive for learning what students think about the library and reference services, what types of sources they use to complete their assignments, and what they believe would be most effective in marketing reference services to their peers.

A major outcome of this project is the realization that, to be effective in our continued desire to increase interactions between students and librarians, we must continue to seek ways to include students in the conversation about how to design and promote our services. Because the needs of our students, technology, and the world of information constantly change, we need to view this process as ongoing. Future plans include seeking student input on content for instruction programs in the classroom (currently, when designing instruction sessions, librarians work only with the faculty member teaching the course). In addition, we will seek student involvement to help us understand how we can increase faculty's efforts to encourage students to use library resources.

From the students' prospective, working with the library was an eye-opening experience. Initially, many marketing students make an "if you build it, they will come" assumption about marketing practices. They seem to believe that at- 
tracting and retaining a customer base is as simple as creating a quality product. From the early stages of the Ames Library project, it was clear that this belief would not hold true. Anecdotal evidence and the survey results both suggest that IWU students found the Ames Library librarians to be well-trained, pleasant experts; yet, when IWU students came to the library, they did not utilize the quality research assistance available to them.

Facing a second, related common marketing mistake helped the students understand why creation of a quality product does not ensure business success. Through the creation of the marketing communication campaigns for the Ames Library, the students began to understand that telling customers, in this case their own classmates and roommates, about the fine attributes of Ames Library was not enough to prevent their friends from relying solely on Google ${ }^{\circledR}$. Many marketers make the mistake of believing that outlining what a product can do is all that is necessary to attract customers. However, in reality, what consumers and library patrons need to hear is what the product can do for them. For the marketing communication campaigns, the students needed to articulate what Ames Library could do for their friends by explaining the benefits of stepping away from Google $^{\circledR}$ and consulting librarians. The campaigns, then, become not about the library and its fine qualities but about the students and their needs.

All told, the use of experiential learning projects in the marketing courses was of great benefit to the students. Practical experience overcoming common marketing mistakes provided the IWU students a chance to see marketing in action, as opposed to hearing about it in lectures and reading about it in print. Additionally, the students learned more about the resources available to them at the Ames Library. Therefore, students gained discipline-specific experience, as well as learning more about resources available to them through libraries. At a liberal arts institution, teaching moments that incorporate the best of a discipline while building a student's world view are the ultimate goal.

\section{Notes}

1. "The Ames Library Building Survey" (conducted by Sheehan Library, Illinois Wesleyan University, 1996).

2. Yvonne Nalani and Ann Manning Fiegen Meulemans, "Using Business Student Consultants to Benchmark and Develop a Library Marketing Plan," Journal of Business and Finance Librarianship 11, no. 3 (2006): 19-31.

3. Robert B. McGeachin and Diana Ramirez, "Collaborating with Students to Develop an Advertising Campaign," College and Undergraduate Libraries 12, no. 1/2 (2005): 139-52.

4. Timothy R. Graeff, "Bringing Reflective Learning to the Marketing Research Course: A Cooperative Learning Project Using Intergoup Critique," Journal of Marketing Education 19 (Spring 1997): 53-64; Philip A. Titus and-Susan M. Petroshius, "Bringing Consumer Behavior to the Workbench: An Experiential Approach," Journal of Marketing Education 15 (Spring 1993): 20-30; David L. Williams, John D. Beard, and Jone Rymer, “Team Projects: Achieving Their Full Potential," Journal of Marketing Education 11 (Summer 1991): 64-71.

5. Nabil Y. Razzouk, Victoria Seitz, and Elias Rizkallah, "Learning by Doing: Using Experiential Projects in the Undergraduate Marketing Strategy Course," Marketing Education Review 13, no. 2 (2003): 35-41.

6. Terri Feldman Barr and Kevin M. McNeilly, “The Value of Students' Classroom Experiences From the Eyes of the Recruiter: Information, Implications, and Recommendations for Marketing Educators," Journal of Marketing Education 24, no. 2 (2002): 168-73; Ellen J. Kennedy, Leigh Lawton, and Erika Walker, "The Project Approach to Teaching the Capstone Marketing Course," Journal of Marketing Education 12, no. 2 (2001): 37-48.

7. Richard R. Klink and Gerard A. Athaide, "Implementing Service Learning in the Principles of Marketing Course," Journal of Marketing Education 26, no. 2 (2004): 145-53.

8. Klink and Athaide, "Implementing Service Learning"; Tara Burnthorne Lopez and Renee Gravois Lee, "Five Principles for Workable Client-Based Projects: Lessons from the Trenches," 
Journal of Marketing Education 27, no. 2 (2005): 172-88.

9. Charles Martell, "The Elusive User: Changing Use Patterns in Academic Libraries 1995 to 2004," College and Research Libraries 68, no. 5 (2007): 435-44.

10. Susan Gardner, “Tiered Reference: The New Landscape of the Frontlines," Electronic Journal of Academic and Special Librarianship 7, no. 3 (2006). Available online at; http://southernlibrarianship.icaap.org/content/v07n03/gardner_s01.htm. Accessed March 17, 2008.

11. Mary Warnement, "Size Matters: The Debate over Reference Desk Height," Portal:-Libraries and the Academy 3, no. 1 (2003):-79-87.

12. Klink and Athaide, "Implementing Service Learning," 145-53.

13. Neil Howe and William Strauss, Millennials Go to College: Strategies for a New Generation on Campus: Recruiting and Admissions, Campus Life, and the Classroom (Washington, DC: American Association of Collegiate Registrars and Admissions Officers American and LifeCourse Associates, 2003).

14. Ibid.

15. Ibid.

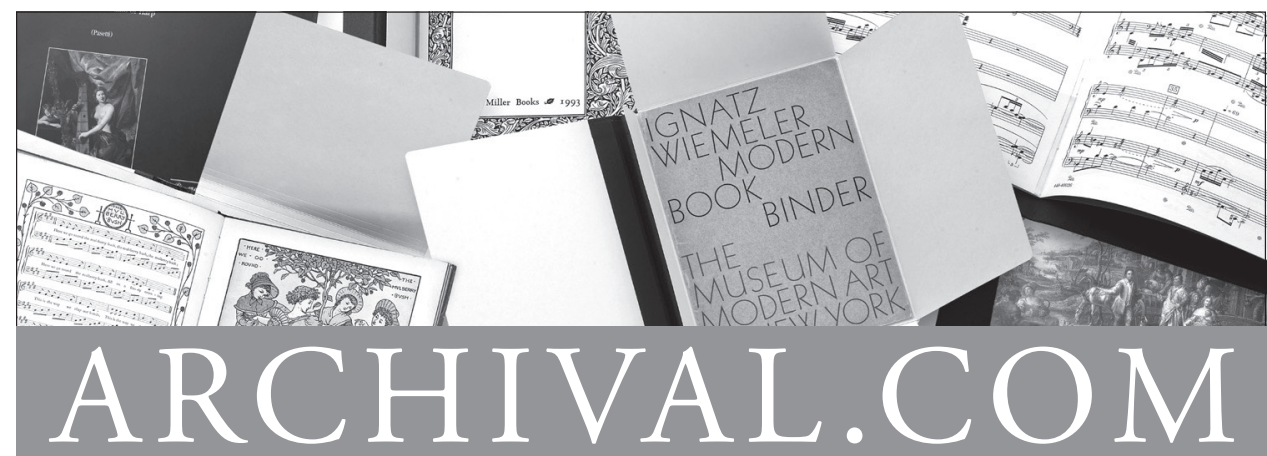

INNOVATIVE SOLUTIONS FOR PRESERVATION

Call for a complete catalog

Pamphlet Binders

Music Binders

Archival Folders

Manuscript Folders

Hinge Board Covers

Academy Folders

Newspaper/Map Folders

Bound Four Flap

Enclosures

Archival Binders
Polypropylene Sheet \& Photo Protectors Archival Boards Adhesives

Bookkeeper

Century Boxes

Conservation Cloths

Non-Glare Polypropylene Book Covers

CoLibri Book Cover System

\section{ARCHIVAL PRODUCTS}

P.O. Box 1413

Des Moines, Iowa 50306-1413

Phone: 800.526 .5640

Fax: 888.220.2397

E-mail: custserv@archival.com Web: archival.com 


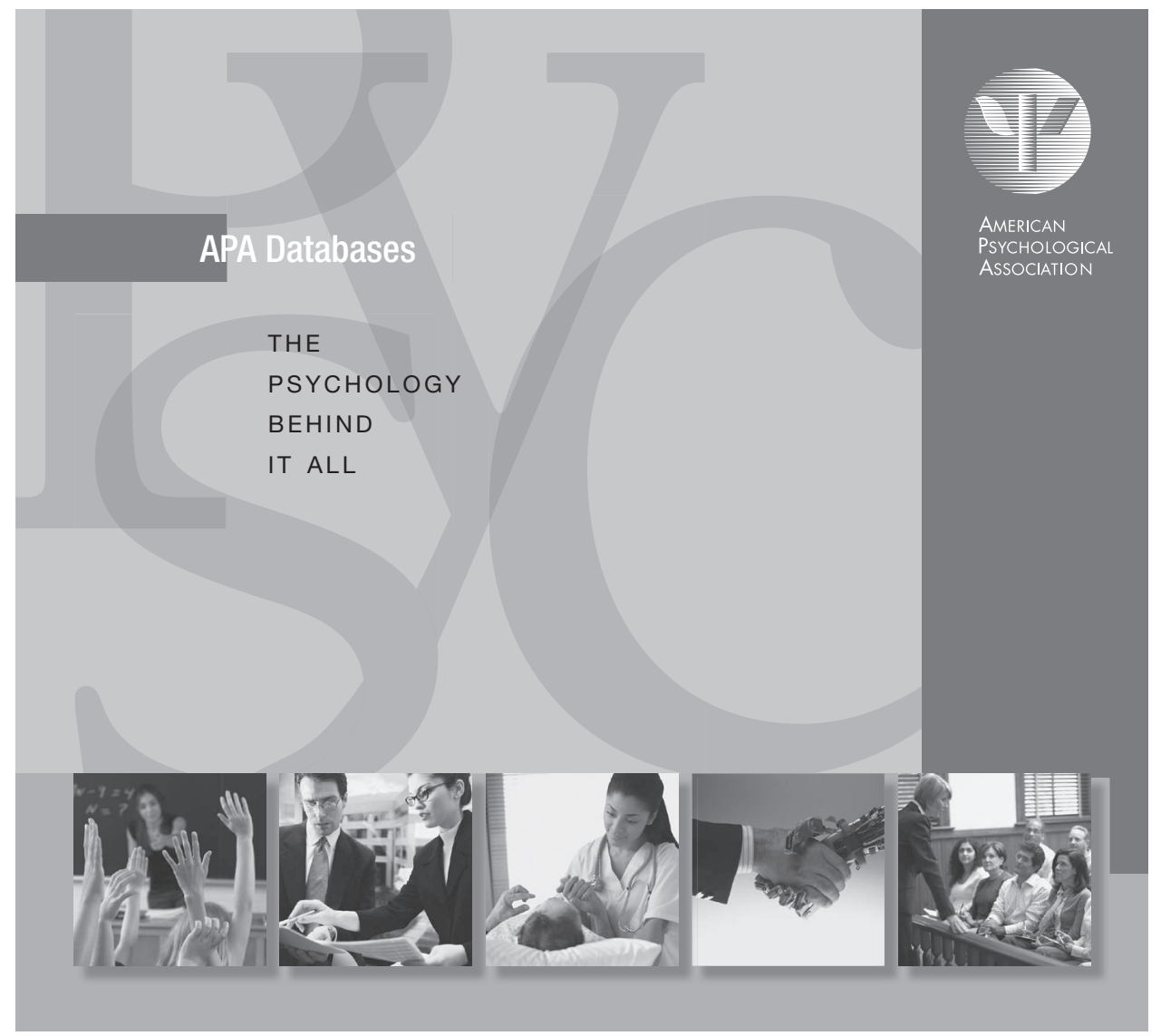

\section{Focused Research, Multidisciplinary Impact}

Psychological research is vital to understanding the impact of behavior and its role in addressing today's interdisciplinary challenges in areas such as education, business, health science, technology, and law. APA's suite of databases provides comprehensive coverage of the international behavioral sciences literature, including full-text journal and book content, in addition to gray literature and much more. With this information, you can build an integrated core collection that supports the programs, coursework, research and practices throughout your institution.

Contact APA today for a free 30-day trial on APA PsycNET ${ }^{\circledR}$, APA's state-ofthe-art search platform by visiting www.apa.org/freetrials, calling APA at 800-374-2722 or 202-336-5650, or emailing ftr@apa.org.

Visit APA booth \# 1 42I at ACRL 2009 for a demonstration of APA PsycNET. 